\title{
Chemistry Learning Through Practicum With Household Materials During The Covid-19 Pandemic
}

\author{
Rini Sugiarti', Sunyono ${ }^{2, *}$ \\ ${ }^{1}$ Sekolah Menegah Kejuruan Negeri 1 Natar, Indonesia. \\ ${ }^{2}$ Department of Chemical Education, Universitas Lampung, Indonesia. \\ *Corresponding email: sunyono.1965@fkip.unila.ac.id
}

Received: 13 March 2021

Accepted: 23 April 2021

Published: 30 April 2021

Abstract: Learning Chemistry Through Practicum With Household Materials During the Covid-19 Pandemic. Purpose: This study aims to improve students' learning interest and understanding the chemical concepts after participating in chemistry learning through practicum using household chemical materials during the Covid-19 pandemic. Method: This research was conducted through the classroom action research with three cycles of action. The research was conducted on Grade X SMKN 1 Natar Lampung Selatan with 32 students. Finding: After learning, it was found that (1) there is an increase of student interest in the category of "very high" $79.84 \%$ and "high" amounting to $12.03 \%$, other categories are the low category of $7.19 \%$ and $0.94 \%$ very low category. (2) Students' understanding of chemistry concepts increased from cycle to cycle with an increase in cycle 1 to cycle 2 of 2.00 points and from cycle 2 to cycle 3 of 8.50 points. Conclusion: The online chemistry study during the Covid-19 pandemic through practicum using household chemical materials can increase students' learning interest and understanding of chemistry concepts.

Keywords: chemistry practicum, household chemical materials; Covid-19 pandemic.

Abstrak: Pembelajaran Kimia Melalui Praktikum Dengan Bahan Rumah Tangga Selama Pandemi Covid-19. Tujuan: Penelitian ini bertujuan untuk meningkatkan minat belajar dan pemahaman konsep kimia siswa setelah mengikuti pembelajaran kimia melalui praktikum menggunakan bahan kimia rumah tangga pada saat pandemi Covid-19. Metode: Penelitian ini dilaksanakan melalui penelitian tindakan kelas dengan tiga siklus tindakan. Penelitian dilakukan pada siswa kelas X SMKN 1 Natar Lampung Selatan dengan jumlah siswa 32 siswa. Temuan: Setelah pembelajaran ditemukan bahwa (1) terjadi peningkatan minat siswa pada kategori "sangat tinggi" 79,84\% dan "tinggi" sebesar 12,03\%, kategori lainnya pada kategori rendah sebesar 7,19\% dan 0,94\%. kategori sangat rendah. (2) Pemahaman konsep kimia siswa meningkat dari siklus ke siklus dengan peningkatan pada siklus 1 ke siklus 2 sebesar 2,00 poin dan dari siklus 2 ke siklus 3 sebesar 8,50 poin. Kesimpulan: Pembelajaran kimia online pada masa pandemi Covid-19 melalui praktikum menggunakan bahan kimia rumah tangga dapat meningkatkan minat belajar dan pemahaman konsep kimia siswa.

Kata kunci: praktikum kimia, bahan kimia rumah tangga, pandemi covid19.

\section{To cite this article:}

Sugiarti, R., \& Sunyono. (2021). Chemistry Learning Through Practicum with Household Materials During the Covid-19 Pandemic. Jurnal Pendidikan Progresif, 11(1), 129-174. doi: 10.23960/ jpp.v11.i1.202111. 


\section{INTRODUCTION}

The implementation of learning is the most important matter in the world of education, where learning should involve a process of interaction between students and teachers and interactions between students themselves as well as the use of relevant learning resources in a learning environment, especially in science learning such as chemistry. In connection with the chemistry learning system, Wood (2006: 96) and BouJaoude \& Barakat (2003) state that in studying chemistry, students must be trained in developing thinking skills to solve problems, especially those related to the daily environment. Hence, achievement in delivering chemistry materials through such learning needs to be measured using a variety of problems at the molecular level that can be solved by the students appropriately and meaningfully. However, the problem is that the learning of chemistry has so far met many problems in the field. Among them are related to the ability of students to understand chemistry materials and implement chemistry in everyday life (Davidowitz, Chittleborough, \& Eileen, 2010; Liliasari, 2007: Sunyono \& Efkar, 2020). This problem will become sharper after the emergence of the Covid-19 pandemic that has hit the world, including Indonesia.

Covid-19 is a new type of corona virus that previously could not be identified to be in humans (Hernandez and Ramzy, 2020), but in fact researchers later confirmed that the virus can be transmitted from person to person through droplets of fluid that comes out when coughing or sneezing (Huang, Wang, Ren, Zhao, Yi Hu, Zhang, ...., \& Cao, 2020: Li, Guan, Wu, Wang, Zhou, Tong, ..., \& Feng, 2020). With the emergence of Covid-19 pandemic, the government decided to implement a range of policies to prevent the spread of the corona virus among other social and physical distancing or large-scale social restrictions (pembatasan sosial berskala besar or PSBB) with appeals from the government to stay at home, live a healthy lifestyle, refraining from touching the facial area, and always using a mask when forced to go out (Jamaluddin, Ratnasih, Gunawan, \& Paujiah, 2020). The Covid-19 pandemic appears to have changed the social order of society to become a factor that greatly affects the current learning process (Strielkowski, 2020). In this case, large-scale physical and social activities restrictions prevent learning to be carried out face-to-face, thus having a major impact on the learning process activities that must be carried out face-to-face, especially chemistry learning which requires practicum activities.

Chemistry learning requiring practicum activities are actually quite necessary for training of various skills, especially psychomotor abilities that must be possessed by students in chemistry learning because chemistry requires discovery and investigation activities in solving problems. As one branch of science, where the process of development and application of knowledge strongly requires empirical studies in the laboratory with certain standards, chemistry learning cannot be done only theoretically and verbally (Faika \& Side, 2011). With the application of health protocols in the Covid-19 pandemic, at various institutions including schools, activities of laboratory experiments as it should be are certainly not possible. Yet, the essence of chemistry learning is based on process, product, and attitude. Thus laboratory activities in chemistry learning cannot just be simply taken out.

The implementation of chemistry learning coupled with chemistry practicum activities is a chemistry learning step that has been considered effective in increasing student knowledge because such learning activities not only improve students' conceptual and cognitive understanding, but can also shape student skills in terms of observation, data collection, problem solving, teamwork, and 
also communication skills (Rokhim, Asrori, \& Widarti, 2020). Therefore, even with the existence of government policies on working and learning from home through online learning, teachers need to be innovative and creative, so that chemistry learning does not lose its essence.

Several survey research results on online learning found that more than $60 \%$ of students stated that they were used to implementing online learning and half of the respondents stated that the online system made the process easier. Even so, there is a tendency for students to be faced with several problems, both technical and related to students' understanding of the materials being learned (Jamaluddin, et al., 2020; Darmalaksana, Hambali, Masrur, \& Ushuluddin, 2020). If we look at the results of the survey research, it seems that they are still general in nature, not yet focused on research on how the performance/activities of students are in participating in chemistry learning, including how chemistry practicum activities are carried out online. Other studies have included virtual chemistry practicum activities by developing virtual laboratories to substitute chemistry practicum activities in real laboratories (Fadhillah \& Andromeda, 2020; Ekaputra, 2020), but the weakness of these virtual laboratories is that they do not provide real direct experience, so that students' observation skills are weak and there is a lack of ability to solve problems (Nirwana, 2011).

Based on the description above, this paper discusses the results of research that was carried out some time ago at SMKN 1 Natar, namely the implementation of a simple chemistry practicum through videos in chemistry learning during the Covid-19 Pandemic. In this paper, we will describe the implementation of chemistry practicum-based learning with household chemical materials and can be done by students themselves at home. Results of this research is the answer to questions: (1) How is the increase of students' interest towards the subject of chemistry through simple practical methods with household equipment and materials that are easy to obtain during the pandemic? (2) How is the increase of students' understanding of chemistry concepts through practicum methods with household equipment and materials that are easily obtained and can be done by students themselves during the Covid-19 pandemic? Furthermore, the article on the results of this research is expected to provide an alternative solution to the problem of chemistry learning during the Covid-19 Pandemic.

\section{METHODS \\ Research design}

The research utilizes the classroom action research (PTK) because through this PTK one expects to improve the previous learning process and improve student learning results. The action research carried out includes three cycles and each cycle consists of four stages, namely planning, action, observation, and reflection.

\section{Research Participants}

Research was conducted at SMKN 1 Natar in Grade X, Computer and Network Engineering Departement(Teknik Komputer dan Jaringan / TKJ) during the odd numbered semester in the 2020/2021 Academic Year, with as many as 32 students. This number consists of 13 male and 19 female students. This research was conducted between August and October, starting from the planning stage (syllabus preparation, Lessons Implementation Plan or RPP, Practicum Guide, preparation of equipment and materials, practicum trials, and refinement of the Practicum Guide), learning implementation, observation/evaluation, and finally reflection.

\section{Research procedure}

The implementation of the classroom action research carried out includes 3 cycles, namely: First cycle: In this cycle the subject matter, which 
is the core of learning, is materials and its transformations with its sub-subject of physical and chemical transformations. The implementation of learning activities begins with the delivery of a practicum video via a YouTube URL link that the teacher does ( 30 minutes before learning), then virtual face-to-face (Vi-Con) through google meet for 15 minutes, the teacher opens the lesson by asking questions to find out the students' mastery of previous chemistry concepts and related to the material to be studied. For example about chemical and physical transformations that are often encountered everyday (such as melting ice cubes, burning candle wicks, the process of making tapai (slightly fermented sweet cakes), burning wood, reaction of vinegar acid with baking soda, reaction of carbide with water and others). At the end of the meeting students were given materials that have been shared on Learning Management System (LMS). Students read and understand the material and ask questions if anything is unclear. Discussions between teachers and students, as well as discussions between students, are done through WhatsApp group (WA). After one sub-subject has been completed, a formative test is then carried out to see the level of students' understanding of the chemistry concepts in question. At the end of the cycle, reflection is carried out to examine the learning strategies provided by the teacher and to assess changes in student behavior during and after actions were applied. The results of the reflection are used as a reference in making new action plans in the next cycle.

The second cycle: The Sub-Subject discussion provided in the second cycle is the chemical reactions that produce gas. The actions taken were: the teacher explains the practicum procedure through a video uploaded on YouTube (30 minutes before the lesson). Next, the students do practicum work themselves using equipment and materials available at home. The students then recorded and made a video of the practicum they did. The lesson of the second cycle is ended by answering the questions in the LMS.

The third cycle: The Sub-Subject that given in the third cycle are chemical reactions that produce explosions. The implementation of the action is the same as in the second cycle, only in the third cycle the teacher calls 2 students to come to school under the health protocol. The teacher and students perform an experiment demonstration of an explosive reaction with household chemicals. Then the two students recorded and made a video of the practicum which they did with the teacher. Other students watch the video using the YouTube URL provided by the teacher through WA and subsequently students were asked to answer the questions of the teacher in the LMS and group discussions in WA.

\section{Research Data Analysis and Instruments}

The instruments used in this study was a test, a questionnaire (questionnaire), and observation sheet. The test was used to see the achievement of students' concept understanding after participating in learning through practicum activities from cycle to cycle. Understanding of the concept is measured using multiple choice questions with five alternative answers to as many as 20 items in such test. The test questions were used as questions to see the students' understanding of concepts at the end of each cycle. The instrument in the form of a questionnaire was used to reveal whether there was an increase in students' interest in chemistry learning after being given the action. The questionnaire consists of 20 statements using a 4 point Likert scale: strongly agree (SA), agree (A), disagree (D), and strongly disagree (SD), with consecutive scores of $4,3,2$, and 1 . Observation sheets were carried out to see student activities in online learning. This observation is carried out by the teacher as a 
researcher. The focus of observation were students who ask questions through the WA group, view the video on YouTube being given, and observation to exercise answers and conclusions given by the student.

The analysis was carried out descriptively, both on data about the results of observations, data about student interests, and data on students' conceptual understanding. Observation results data were analyzed by making a percentage of students who were active in learning, either through WA, LMS, or YouTube. Likewise, data on student interest, the percentage of interest scores obtained, were further described into the "very high", "high", "low", and "very low" categories. The data about the students" understanding of concepts in each cycle were analyzed by making the average score of the students for each cycle.

\section{RESULTS AND DISCUSSION}

Student activity data was obtained from observations of videos that were provided with YouTube links to students via a WhatsApp (WA) group and LMS during the learning process in cycle I, cycle II and cycle III. The results of the analysis of activity data are shown in Figure 1.below.

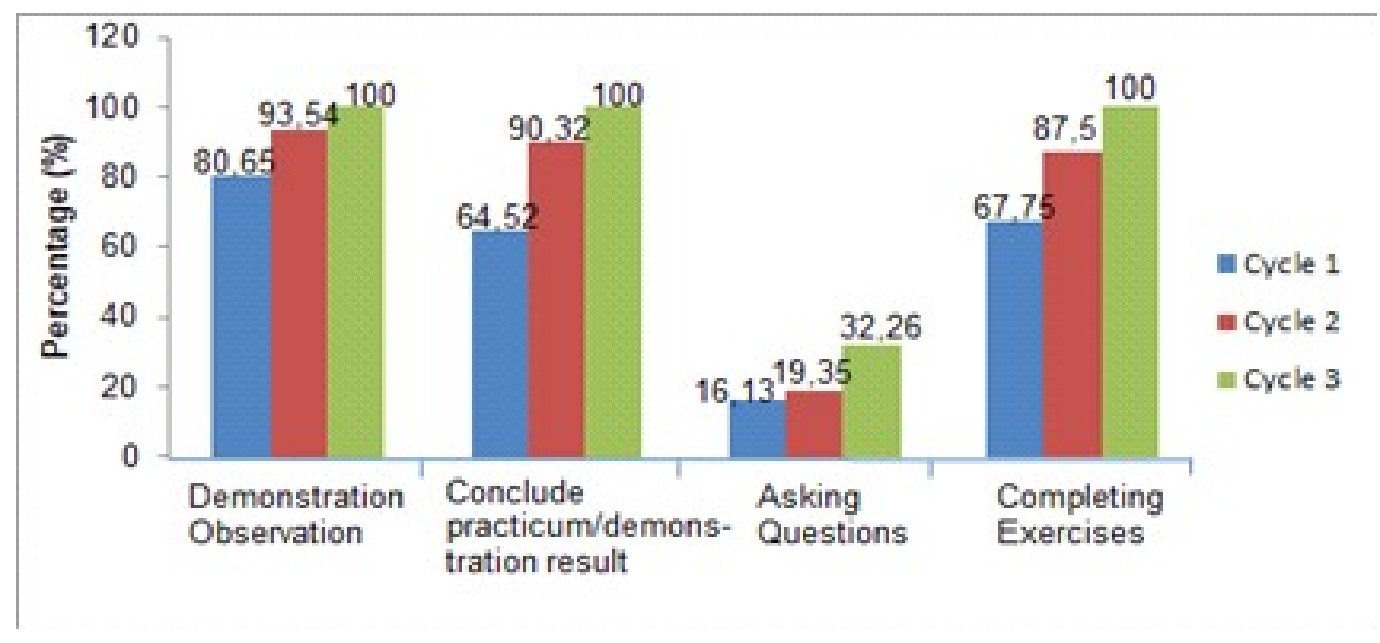

Figure 1. Student learning activities percentages from cycle to cycle

Figure 1. Demonstrates that there is an increase in student learning activities from cycle to cycle. The highest increase in cycle 1 to cycle 2 lies in the aspect of "concluding the results of the practicum / demonstration" increased by $25.80 \%$ and the aspect of "completing the exercise" increased by $19.75 \%$. While the highest increase of cycle 2 to cycle 3 lies in the aspect of "asking questions" amounting to $12.91 \%$. However, the aspect of "demonstration observation", "conclude practicum/ demonstration results", and "completing exercises" in cycle 3 reached $100 \%$. This means that all Grade X TKJ SMKN 1 Natar students are very active in participating in learning through practicum/demonstration activities using household chemical materials.

The increase in student learning activities is due to the role of the teacher as a facilitator in online learning through practicum which has made students feel happy and comfortable in participating in online learning. In this case, the 
teacher provides attention, guidance, and direction to students to ask questions, make conclusions, carry out exercises given online, and study the material provided in $M S$-word and pdf form through the LMS. This finding is in line with Mas (2008:1) statement that teachers in learning activities must act as motivators, facilitators, provide spirit, and provide inspiration to students. The results of this study seem to indicate that the implementation of online chemistry learning during the Covid-19 pandemic through practicum/ demonstration activities using household chemical materials were able to increase students' chemistry learning activities. This is in accordance with the results of community service carried out by Purnavita, Sutanti, \& Sriyana (2020) who concluded that the learning process through practicum with household materials received a positive response, both from teachers and students, and students felt the benefits of learning in the form of understanding and increase of knowledge of the field of applied chemistry, so as to increase the enthusiasm of students in studying chemistry. Furthermore, Sunyono \& Efkar (2020) in their research concluded that chemistry learning carried out on the basis of socio-scientific issues with everyday chemical materials increases student learning activities in class, namely in asking questions, carrying out practicum, providing responses, and doing exercises.

The high student learning activity is also supported by data on student interest in learning. Student interest data in chemistry learning were obtained through filling out a questionnaire. The questionnaire was filled in at the end of the lesson after the post test was carried out. The results of data analysis about students' interest in chemistry learning after being given lessons through online practicum/demonstration activities can be seen in Figure 2. below.

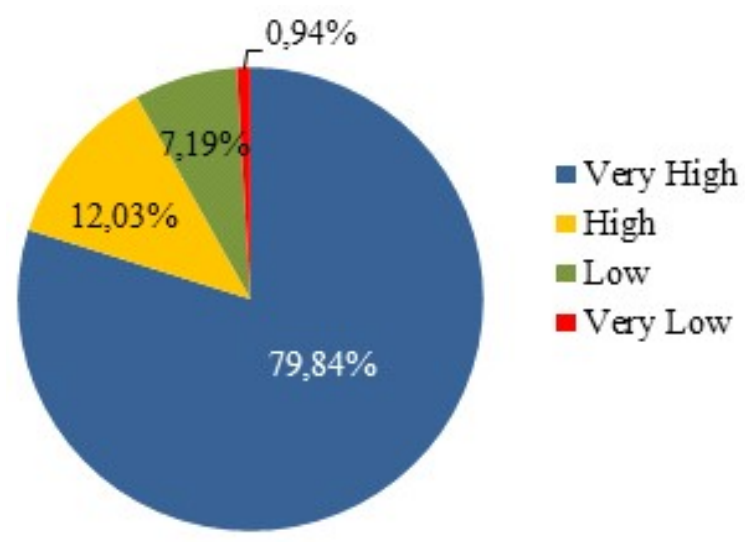

Figure 2. Percentage of students under the interest category.

Figure 2. It shows that students' interest and inquisitiveness in participating in learning activities through practicum/demonstration activities with equipment and materials at home is in the category of "high", where interest in learning is "very high" reaching 79.84\% and "high" as much as $12.03 \%$, and others categorized as "low" and "very low", namely $7.19 \%$ and $0.94 \%$, respectively. This can be seen from the students' answers to each statement item which shows that in all items, students feel strong agreement to participate in learning activities through practicum with equipment and materials at home (more than $80 \%$ of students).

Judging from the students' answers to each statement item on the interest questionnaire, it seems that there are two items that the students answered "disagree" and "strongly disagree". In item 13 the number of students who answered "strongly agree" were as many as 11 students, 6 students answered "agree" and two students answered "disagree" and others (13) answered "strongly disagree". Similarly, in item 16, the students who answered "strongly agree" were only 10 students, the next 8 answered "agree" and 14 students answered "disagree". Although 
there were students who answered "disagree" and "strongly disagree" on items 13 and 16, overall it shows that students' interest in chemistry learning through online practicum/demonstration activities can be categorized as "high" (79.84\% average). This is also supported by data on student responses to learning, where $93.75 \%$ of students responded positively to the use of the practicum/ demonstration method with equipment and materials at home in the learning process. The results of this study appears to be supported by previous studies that concluded there is a significant influence of a laboratory-assisted (virtual) online learning to the interest of students (Dewa, Mukin, \& Pandango, 2020). Similarly, research conducted by Apriyanto \& Herlina (2020) that good management of learning from teachers during the Covid-19 pandemic can stimulate the interest of students to be active in learning and performing online tasks.

Test data on concept understanding materials is taught to students online from cycle to cycle can be seen in Figure 3 below.

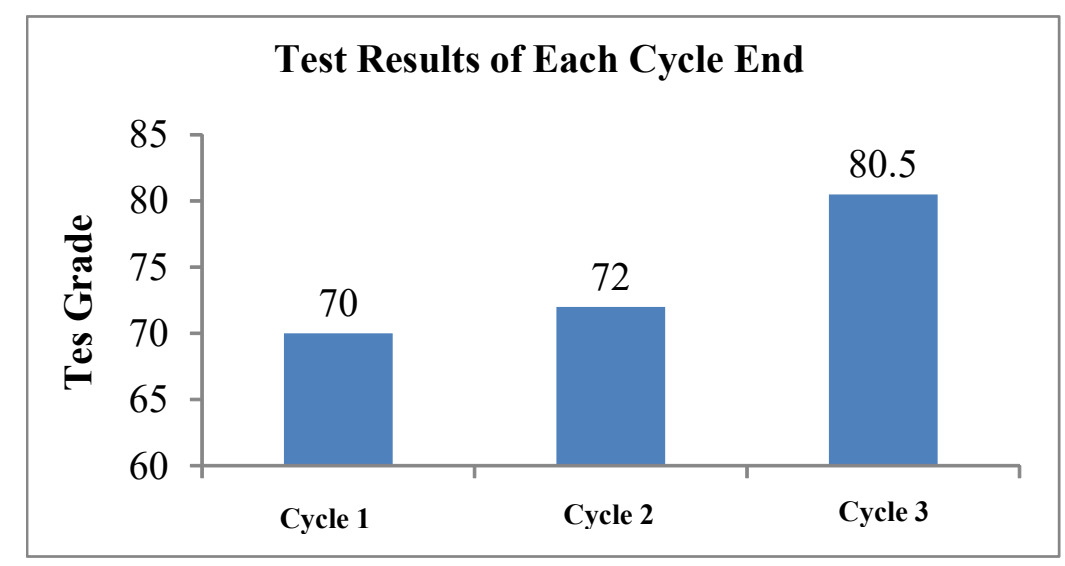

Figure 3. The results of the student material mastery test at the end of each cycle

Figure 3 shows that students' conceptual understanding of the materials being studied has increased from cycle to cycle. This can be seen from the average score of the end of cycle 1 test of 70.00, in cycle 2 of 72.00, and in cycle 3 of 80.50. The increase in the results of students' concept understanding tests from cycle 1 to cycle 2 was 2.00 points and from cycle 2 to cycle 3 was 8.50 points. The average increase of student scores at the end of the test cycle could be achieved well. The achievement is due to students being accustomed to learning utilizing equipment and materials available at home as media in the activities of practicum/demonstrations. In addition, the very high (Figure 1) enthusiasm/ activity of students in learning contributes to increasing students' conceptual understanding of the material being studied from cycle to cycle.

The above research results indicate that learning through practicum/demonstration activities, even though it is carried out online, can form students' understanding of concepts. This is in line with the research results of Brickman, Zahra, Muraskin, Steffener, Holland, Habeck,..., \& Stern (2009), which concluded that high learning activities of students in learning through experimental or practicum activities, carried out during lessons, function as an event to gain knowledge, where students are invited to seek, try, and obtain their own concepts in groups, so that students can discuss and find the concepts they are looking for to be discussed in order to 
finalize these concepts. The results of this study are also supported by the results of research by Saraswati \& Mertayasa (2020) which concluded that in general, practicum learning carried out online is able to produce concept mastery that is not inferior to offline learning.

\section{- CONCLUSIONS}

Based on the research results, it can be stated that chemistry learning through practicum activities with household chemical materials carried out online during the Covid-19 pandemic can increase student enthusiasm during learning, either in cycle 1 , cycle 2 , and cycle 3 . This increased enthusiasm indicates passion in learning in lessons utilizing household chemical materials for practicum during the Covid-19 pandemic. Thus it can be concluded that chemistry learning through practicum activities with household chemical materials during the Covid-19 pandemic was able to: (1) increase students' interest in chemistry learning with a category of "high". (2) Improve students' understanding of chemistry concepts to the lessons being studied from cycle to cycle. Therefore, online learning during the Covid-19 pandemic needs to be designed as well as possible, especially for subjects such as chemistry, practicum/demonstration activities must still be carried out by teachers, so that chemistry learning is not just teaching theory.

\section{REFERENCES}

Apriyanto, M. T., \& Herlina, L. (2020). Analisis Prestasi Belajar Matematika pada Masa Pandemi Ditinjau dari Minat Belajar Siswa. Diskusi Panel Nasional Pendidikan Matematika. Tersedia pada http://proceeding.unindra.ac.id/index.php/ DPNPMunindra/article/viewFile/4774/ 724. Diakses Tanggal 8 Januari 2021.

BouJaoude, S., and Barakat, H. (2003). Students Problem Solving Strategies in Stoichiometry and their Relationships to
Conceptual Understanding and Learning Approaches. Electronic Journal of Science Education. 7 (3). http:// ejse.southwestern.edu/article/view/7709/ $\underline{5476}$.

Brickman, A. M., Zahra, A., Muraskin, J., Steffener, J., Holland, C. M., Habeck, C., .... \& Stern, Y. (2009). Reduction in cerebral blood flow in areas appearing as white matter hyperintensities on magnetic resonance imaging. Psychiatry Research: Neuroimaging, 172(2), 117-120. http:// doi.org/10.1016/j.pscychresns. 2008.11.006.

Darmalaksana, W., Hambali, R. Y. A., Masrur, A., \& Ushuluddin, F. (2020). Analisis Pembelajaran Online Masa WFH Pandemic Covid-19 sebagai Tantangan Pemimpin Digital Abad 21. Karya Tulis Ilmiah (KTI) Masa Work From Home (WFH) Covid-19. UIN Sunan Gunung Djati. Bandung. 1-12. http:// digilib.uinsgd.ac.id/30434/1/ $11042020 \% 2015.30 \% 20$ KTI.pdf.

Davidowitz, B., Chittleborough, G.D., and Eileen, M. (2010). Student-generated submicro diagrams: a useful tool for teaching and learning chemical equations and stoichiometry. Chem. Educ. Res. Pract. 11, 154-164. http://doi.org/10.1039/ C005464J.

Dewa, E., Mukin, M. U. J., \& Pandango, O. (2020). Pengaruh pembelajaran daring berbantuan laboratorium virtual terhadap minat dan hasil belajar kognitif fisika. Jurnal Riset Teknologi dan Inovasi Pendidikan (JARTIKA), 3(2), 351-359. https://doi.org/10.36765/jartika.v3i2.288. Ekaputra, F. (2020). Efektivitas Penerapan Poseidon Meeting Classroom Berbasis Pendekatan Ilmiah Materi Stoikiometri terhadap Motivasi dan Prestasi Belajar Peserta Didik SMA Muhammadiyah 1 
Yogyakarta. VEKTOR: Jurnal Pendidikan IPA, 1(2), 59-65. http:// vektor.iain-jember.ac.id/.

Fadhillah, F., \& Andromeda, A. (2020). Validitas dan Praktikalitas E-Modul Berbasis Inkuiri Terbimbing Terintegrasi Laboratorium Virtual pada Materi Hidrolisis Garam kelas XI SMA/MA. Jurnal Eksakta Pendidikan (JEP), 4(2), 179-188. https:/ /doi.org/10.24036/jep.v1i2.50.

Faika, S., \& Side, S. (2013). Analisis kesulitan mahasiswa dalam perkuliahan dan praktikum kimia dasar di jurusan kimia FMIPA Universitas Negeri Makassar. Chemica: Jurnal Ilmiah Kimia dan Pendidikan Kimia, 12(2), 18-26. http:// dx.doi.org/10.35580/chemica.v12i2.497.

Hernández, J. C., \& Ramzy, A. (2020). China confirms new coronavirus spreads from humans to humans. New York Times. January, 20. https://www.nytimes.com/ 2020/01/20/world/asia/coronaviruschinasymptoms.html. Diakses: 7 Januari 2020.

Huang, C., Wang, Y., Li, X., Ren, L., Zhao, J., Yi Hu., Zhang, L., Fan, G., .... , \& Cao, B. (2020). Clinical features of patients infected with 2019 novel coronavirus in Wuhan, China. Lancet. 395. 497-506. https://doi.org/10.1016/S01406736(20) 30183-5.

Jamaluddin, Ratnasih, T., Gunawan, H., \& Paujiah, E. (2020). Pembelajaran daring masa pandemik Covid-19 pada calon guru: hambatan, solusi dan proyeksi. LP2M UIN Sunan Gunung Djati, Bandung. https://core.ac.uk/download/pdf/ 305072868.pdf. Diakses pada 7 Januari 2021.

Li, Q., Guan, X., Wu, P., Wang, X., Zhou, L., Tong, Y., ... \& Feng, Z. (2020). Early transmission dynamics in Wuhan, China, of novel coronavirus-infected pneumonia. New England Journal of Medicine. 382. No. 13: 1199 - 1207. https://doi.org/ 10.1056/NEJMoa2001316.

Liliasari. (2007). Scientific Concepts and Generic Science Skills Relationship In The 21st Century Science Education. Seminar Proceeding of The First International Seminar of Science Education., 27 October 2007. Bandung. $13-18$.

Mas, S. R. (2008). Profesionalitas Guru dalam Peningkatan Kualitas Pembelajaran. Jurnal Inovasi, 5(2). Tersedia pada https:/ /ejurnal.ung.ac.id/index.php/JIN/ article/ view/797. Diakses tanggal 8 Januari 202.

Purnavita, S., Sutanti, S., \& Sriyana, H. Y. (2020). Practice-Based Chemistry Learning with Training on Household Products Manufacturing at SMAN 15 Semarang. Mattawang: Jurnal Pengabdian Masyarakat, 1(2), 55-62. https://doi.org/10.35877/ 454RI.mattawang205.

Rokhim, D., Asrori, M., \& Widarti, H. (2020). Pengembangan Virtual Laboratory Pada Praktikum Pemisahan Kimia Terintegrasi Telefon Pintar. JKTP: Jurnal Kajian Teknologi Pendidikan, 3(2), 216-226. http://doi.org/10.17977/um038v3i22020 p216.

Saraswati, N. L. P. A., \& Mertayasa, I. N. E. (2020). Pembelajaran Praktikum Kimia Pada Masa Pandemi Covid-19: Qualitative Content Analysis Kecenderungan Pemanfaatan Teknologi Daring. Wahana Matematika dan Sains: Jurnal Matematika, Sains, dan Pembelajarannya, 14(2), 144-161. http:/ /dx.doi.org/10.23887/wms.v14i2.28297

Strielkowski, W. (2020). COVID-19 pandemic and the digital revolution in academia and higher education. Preprint (17 April 
2020): 1-6. https://doi.org/10.20944/ preprints202004.0290.v1. Diakses: 8 Januari 2021.

Sunyono \& Efkar, T. (2020). Desain Pembelajaran Kimia Sma Berbasis SosioSaintifik Dalam Meningkatkan Kemampuan Literasi Kimia Dan Efikasi Diri Siswa. Laporan Penelitian Skim Terapan BLU Unila 2020. LPPM Universitas Lampung.

Wood, C. (2006). The Development of Creative Problem Solving in Chemistry. Chem. Educ. Res. Prac. 7 (2). p. 96-113. https:/ /doi.org/10.1039/B6RP90003H. 